\title{
PENGARUH PROGRAM GERAKAN LITERASI SEKOLAH TERHADAP PRESTASI BELAJAR BAHASA INDONESIA SISWA KELAS IX SMP NEGERI 10 KENDARI
}

\author{
Venti Verlia $^{1}$, dan Sahlan ${ }^{2}$ \\ pbsi.fkip.uho@gmail.com \\ 1, 2, Jurusan Pendidikan Bahasa dan Sastra Indonesia, \\ Fakultas Keguruan dan Ilmu Pendidikan, Universitas Halu Oleo \\ Kampus Hijau Bumi Tridharma Anduonohu, Kendari, Indonesia
}

\begin{abstract}
ABSTRAK
Penelitian ini bertujuan untuk mengetahui pengaruh program Gerakan Literasi Sekolah terhadap prestasi belajar Bahasa Indonesia siswa kelas IX di SMP Negeri 10 Kendari. Dalam penelitian ini menggunakan metode ex post facto dan teknik penarikan sampel yaitu stratified sampling. Instrumen yang digunakan berupa angket/kuesioner. Berdasarkan hasil analisis data penelitian, diketahui bahwa ada pengaruh positif yang signifikan antara program Gerakan Literasi Sekolah terhadap prestasi belajar Bahasa Indonesia siswa kelas IX SMP Negeri 10 Kendari. Hasil uji hipotesis menunjukkan bahwa nilai signifikansi (Sig.) sebesar 0,039. Jika dibandingkan dengan nilai probabilitas atau $\alpha=0,05$, maka $0,039<0,05$, yang berarti $\mathrm{H}_{\mathrm{o}}$ ditolak dan $\mathrm{H}_{\mathrm{a}}$ diterima. Jika dilihat dari nilai $\mathrm{t}_{\text {hitung }}$ diperoleh nilai sebesar 2,110 $>\mathrm{t}_{\text {tabel }} 1,994$, sehingga dapat disimpulkan bahwa variabel program Gerakan Literasi Sekolah (X) berpengaruh terhadap variabel prestasi belajar Bahasa Indonesia (Y). Hal ini juga dapat dilihat dari hasil uji koefisien determinasi yang mengungkapkan kontribusi program Gerakan Literasi Sekolah untuk prestasi belajar Bahasa Indonesia adalah $6,1 \%$. Walaupun kontribusi yang diberikan masih sangat rendah, namun jika program tersebut dilaksanakan dengan sangat baik dengan melihat faktor-faktor yang mempengaruhi pelaksanaannya maka pengaruhnya terhadap prestasi belajar Bahasa Indonesia bisa meningkat. Faktor yang mempengaruhi pelaksanaan program Gerakan Literasi Sekolah terdiri dari dua faktor yaitu faktor penghambat yang terdiri dari lingkungan keluarga dan kurangnya petugas literasi, dan faktor pendukung yaitu adanya dukungan dari pihak sekolah dan penyediaan buku yang memadai. Faktor yang mempengaruhi prestasi belajar Bahasa Indonesia siswa terdiri dari faktor internal dan ekternal. Faktor internal yang mempengaruhi prestasi belajar siswa yaitu aspek psikologis yang terdiri dari minat baca dan kemauan siswa sedangkan faktor eksternal yang mempengaruhi yaitu lingkungan sekolah dan keberadaan media sosial.
\end{abstract}

Kata Kunci : Gerakan literasi; Prestasi belajar 


\begin{abstract}
This study aims to determine the effect of the School Literacy Movement program on the Indonesian language learning achievement of grade IX students at SMP Negeri 10 Kendari. In this study using ex post facto method and sampling technique, namely stratified sampling. The instrument used was in the form of a questionnaire. Based on the results of the research data analysis, it is known that there is a significant positive effect between the School Literacy Movement program on the Indonesian language learning achievement of grade IX students of SMP Negeri 10 Kendari. Hypothesis test results show that the significance value (Sig.) Is 0.039. When compared with the probability value or $\alpha=0.05$, then $0.039<0.05$, which means that $H_{0}$ is rejected and $H_{a}$ is accepted. If seen from the tcount value, it is obtained a value of $2.110>t$ table 1.994, so it can be concluded that the School Literacy Movement program variable (X) affects the Indonesian learning achievement variable (Y). This can also be seen from the results of the determination coefficient test which reveals the contribution of the School Literacy Movement program to Indonesian language learning achievement is $6.1 \%$. Although the contribution made is still very low, if the program is implemented very well by looking at the factors that influence its implementation, the impact on Indonesian learning achievement can be increased. The factors that influence the implementation of the School Literacy Movement program consist of two factors, namely inhibiting factors consisting of the family environment and the lack of literacy officers, and supporting factors, namely the support from the school and the provision of adequate books. Factors that affect students' Indonesian learning achievement consist of internal and external factors. Internal factors that affect student achievement are psychological aspects consisting of reading interest and student willingness, while external factors that influence are the school environment and the existence of social media.
\end{abstract}

Keywords: literacy movement; Learning achievement

401 | Jurnal BASTRA (Bahasa dan Sastra), Vol. 5 No.4, Edisi Oktober 2020/e-ISSN: 25033875/ http://ojs.ohu.ac.id/index.php/BASTRA 


\section{PENDAHULUAN}

Keterampilan berbahasa terdiri atas empat keterampilan, yaitu keterampilan menyimak, berbicara, membaca dan menulis. Keempat keterampilan tersebut tentunya saling berhubungan. Keterampilan membaca berperan penting dalam kehidupan kita karena pengetahuan diperoleh dengan membaca. Oleh karena itu, keterampilan membaca harus dikuasai oleh peserta didik sejak dini. Dari sinilah peran minat baca dibutuhkan. Sebab, jika peserta didik sudah bisa membaca maka yang harus ditingkatkan ialah minatnya dalam membaca. Jika peserta didik sudah memiliki minat dan motivasi dalam membaca, maka pengetahuannya tentu semakin luas dan bertambah. Kemudian kemampuan dalam memahami bacaan tentu semakin bertambah pula dan akan berpengaruh juga dengan prestasi belajar siswa.

Membaca merupakan kegiatan penting dalam kehidupan sehari-hari. Selain untuk memperoleh informasi, membaca juga berfungsi sebagai alat untuk memperluas pengetahuan dan wawasan. Dengan membaca, kemampuan dalam memahami kata, berpikir dan kreativitas akan meningkat serta menemukan gagasan-gagasan baru. Keterampilan membaca memiliki peranan penting bagi kehidupan karena segala pengetahuan tidak akan mungkin didapat tanpa membaca. Oleh karena itu, keterampilan membaca penting sekali untuk dikuasai peserta didik dengan baik sejak dini untuk membiasakan budaya membaca.

Kurangnya minat baca masyarakat Indonesia tercatat oleh UNESCO pada tahun 2012 yang menyatakan baru mencapai 0,001 . Artinya, setiap 1000 penduduk, hanya satu orang saja yang memiliki minat baca. Ia menilai rendahnya budaya literasi Indonesia, salah satu penyebabnya karena pejabat dan birokrat pendidikan tidak paham tentang literasi itu sendiri. Akibatnya, literasi tidak menjadi bagian dari kurikulum, termasuk dalam kurikulum 2013. Memang masalah yang sangat kompleks ketika minat baca di kalangan pejabat Indonesia saja sudah sangat kurang sebagaimana dicatat oleh penelitian UNESCO di atas (Imran dkk, 2017: 703).

Gerakan Literasi Sekolah (GLS) memperkuat gerakan penumbuhan budi pekerti sebagaimana dituangkan dalam Peraturan Menteri Pendidikan dan Kebudayaan Nomor 23 Tahun 2015. Salah satu kegiatan di dalam gerakan tersebut adalah "kegiatan 15 menit membaca buku non pelajaran sebelum waktu belajar dimulai”. Dalam penelitian ini, kegiatan literasi diarahkan untuk membaca buku yang berhubungan dengan mata pelajaran Bahasa Indonesia seperti buku fiksi dan nonfiksi. Kegiatan ini dilaksanakan untuk menumbuhkan minat baca peserta didik serta dapat meningkatkan prestasi belajar Bahasa Indonesia siswa.

Gerakan Literasi Sekolah terdiri dari tiga tahap pelaksanaan yaitu pembiasan, pengembangan, dan pembelajaran. Pada tahap pembiasaan kegiatan membaca yang menyenangkan di ekosistem sekolah yang bertujuan untuk menubuhkan minat baca terhadap bacaan. Pada tahap pengembangan, kegiatan literasi bertujuan untuk mengembangkan kemampuan memahami bacaan. Dan pada tahap pembelajaran, kegiatan literasi bertujuan untuk mengembangkan kemampuan memahami teks dan mengaitkannya dengan pengalaman pribadi. Dari ketiga langkah tersebut, diharapkan dapat menumbuhkan kemauan membaca peserta didik dengan pembiasaan membaca setiap awal mulai proses pembelajaran di kelas dan dapat meningkatkan kemampuan siswa dalam memahami bahan bacaan.

Berdasarkan hasil observasi awal yang dilakukan pada tanggal 02 Agustus 2019 di SMP Negeri 10 Kendari, terdapat perubahan dan peningkatan budaya baca setelah diterapkan program Gerakan Literasi Sekolah yang dilakukan dua kali dalam seminggu yaitu pada hari Selasa dan Rabu yang dilakukan 20 menit sebelum mata pelajaran pada jam pertama dimulai. Bahan bacaan yang akan dibaca, tidak harus buku Bahasa Indonesia melainkan siswa diberi kebebasan untuk memilih buku yang akan dibaca dari perpustakaan, namun dalam penelitian ini siswa diarahkan untuk membaca bacaan yang berhubungan dengan mata pelajaran Bahasa Indonesia. Kegiatan literasi ini dilakukan di luar kelas yaitu di lapangan sekolah, hal ini dilakukan agar pelaksanaan kegiatan literasi lebih efektif dan dapat terkontrol dengan mudah. Implementasi kegiatan literasi sekolah ini bertujuan untuk menumbuhkan minat baca siswa, kemudian dengan adanya minat baca siswa dengan pembiasaan 20 menit membaca, kemampuan membaca siswa dapat meningkat. Dalam hal ini, ada tahap pengembangan dan pembelajaran yang bertujuan untuk meningkatkan kemampuan siswa dalam memahami bacaan. 
Bentuk keberhasilan kegiatan literasi dalam pelajaran Bahasa Indonesia di sekolah dapat dilihat dari prestasi belajar siswa, karena prestasi belajar merupakan hasil usaha yang dicapai siswa selama melaksanakan kegiatan belajar di sekolah yang pada umumnya dalam bentuk nilai atau angka. Sesuai dengan ketentuan kurikulum yang berlaku bahwa untuk mengukur keberhasilan pembelajaran yaitu dengan ditetapkannya kriteria ketuntasan minimum atau biasa disebut dengan KKM. Kegiatan literasi di SMP Negeri 10 Kendari mulai dilaksanakan pada semester II tahun pelajaran 2018/2019.

Menurut data verifikasi tahun 2018/2019 di SMP Negeri 10 Kendari sebelum dilaksanakan kegiatan literasi, prestasi belajar siswa dalam hal ini nilai rapor Bahasa Indonesia siswa menunjukkan bahwa dari jumlah keseluruhan siswa kelas VIII yang berjumlah 225 siswa, nilai yang diperoleh siswa masih standar. Berdasarkan data nilai rapor siswa, ada 64 siswa yang mendapatkan nilai 70-79, ada 152 siswa mendapatkan nilai $80-89$, dan ada 9 siswa yang mendapatkan nilai 90-100.

Berdasarkan data awal tersebut menunjukan bahwa sebelum dilaksanakan kegiatan literasi, seluruh siswa mampu memenuhi atau bahkan melampaui KKM yang telah ditetapkan di sekolah, namun dalam penelitian ini peneliti tidak berpatokan pada nilai KKM, tetapi untuk melihat ada atau tidak pengaruh literasi terhadap prestasi belajar siswa peneliti melihat pengaruh dengan membandingkan nilai mata pelajaran Bahasa Indonesia sebelum dilaksanakan kegiatan literasi dengan nilai Bahasa Indonesia setelah dilaksanakan kegiatan literasi.

Berdasarkan permasalahan dan pemikiran yang diuraikan di atas, peneliti akan melakukan penelitian dengan melihat pengaruh setelah dilaksanakannya kegiatan literasi apakah prestasi belajar Bahasa Indonesia siswa lebih meningkat atau bahkan menurun. Oleh karena itu, peneliti tertarik untuk melakukan penelitian dengan judul "Pengaruh Program Gerakan Literasi Sekolah Terhadap Prestasi Belajar Bahasa Indonesia Siswa Kelas IX SMP Negeri 10 Kendari".

Berdasarkan latar belakang yang telah dikemukakan tersebut, maka rumusan masalah dalam penelitian ini yaitu sebagai berikut.

1. Bagaimanakah pengaruh program Gerakan

Literasi Sekolah terhadap prestasi belajar Bahasa Indonesia siswa kelas IX SMP
Negeri 10 Kendari Tahun Pelajaran 2019/2020?

2. Apa saja faktor yang mempengaruhi pelaksanaan program Gerakan Literasi Sekolah terhadap prestasi belajar Bahasa Indonesia siswa kelas IX SMP Negeri 10 Kendari?

Berdasarkan rumusan masalah tersebut, maka tujuan yang akan dicapai dalam penelitian ini yaitu sebagai berikut.

1. Untuk mengetahui seberapa besar pengaruh pelaksanaan program Gerakan Literasi Sekolah untuk meningkatkan prestasi belajar Bahasa Indonesia siswa kelas IX SMP Negeri 10 Kendari Tahun Pelajaran 2019/2020.

2. Untuk mengetahui faktor yang mempengaruhi implementasi program Gerakan Literasi Sekolah terhadap prestasi belajar Bahasa Indonesia siswa kelas IX SMP Negeri 10 Kendari.

Penelitian ini diharapkan dapat bermanfaat untuk mengembangkan konsep-konsep pendidikan, khususnya pendidikan bahasa Indonesia yang mengkaji tentang program Gerakan Literasi Sekolah siswa SMP Negeri 10 Kendari. Manfaat yang diharapkan pada penelitian ini yaitu sebagai berikut.

1. Memberikan gambaran pengaruh program literasi sekolah terhadap prestasi belajar Bahasa Indonesia siswa kelas IX SMP Negeri 10 Kendari.

2. Hasil penelitian ini dapat digunakan sebagai informasi dan penambah wawasan bagi tenaga pendidik dalam rangka melaksanakan Gerakan Literasi Sekolah agar terwujud generasi yang memiliki budaya literasi.

3. Hasil penelitian ini dapat dijadikan tambahan media literatur yang berguna bagi SMP Negeri 10 Kendari agar dapat melaksanakan Gerakan Literasi Sekolah dengan efektif sehingga dapat mencapai tujuan yang dicita-citakan.

4. Hasil penelitian berguna untuk memberikan refeksi kepada masyarakat umum betapa pentingnya membaca dan hasil penelitian ini dapat digunakan oleh siswa sebagai bahan evaluasi diri agar dapat menjadi pribadi yang literat.

Untuk menghindari kesalahan penafsiran karena banyaknya definisi pada penelitian ini, maka perlu adanya batasan operasional untuk memperjelas maksud dari penulis yaitu.

1. Literasi adalah sebuah kemampuan yang kompleks yang dimiliki setiap individu 
untuk menggunakan potensi dan kemampuan yang ada dalam dirinya untuk memahami setiap bacaan, baik itu melalui media cetak ataupun media digital.

2. Gerakan Literasi Sekolah adalah sebuah kegiatan membaca yang dilakukan di luar ruang kelas yaitu di lapangan sekolah selama 20 menit sebelum jam pelajaran pertama dimulai yang diperuntukkan untuk siswa kelas IX SMP Negeri 10 Kendari yang bertujuan untuk menumbuhkembangkan dan meningkatkan minat baca dan budaya literasi dalam mewujudkan bangsa yang berdaya saing yang diharapkan dapat meningkatkan kualitas pendidikan negara Indonesia.

3. Prestasi belajar adalah nilai yang diperoleh oleh siswa kelas IX SMP Negeri 10 Kendari sebagai akibat atau hasil dari proses belajar yang diberikan oleh guru.

Literasi didefiniskan sebagai kemampuan memahami simbol-simbol bahasa atau kemampuan keaksaraan. Dalam pengertian awal ini, literasi dikonsepsikan dalam dua bidang utama, yakni bidang membaca dan menulis permulaan. Berdasarkan cakupan awalnya, literasi dipandang sebagai kondisi melek huruf, melek kata, dan melek makna (Abidin 2017: 7). Kern dalam (Hayat, 2015: 31-33) mengemukakan bahwa terdapat tujuh prinsip pendidikan bahasa berbasis literasi, yaitu sebagai berikut.

1. Literasi berhubungan dengan kegiatan interpretasi. Kegiatan berbahasa pada dasarnya adalah kegiatan interpretasi terhadap realita yang dihadapi dan realita itu ditafsirkan ke dalam penggunaan bahasa. Ketika membaca, sebenarnya kita sedang menginterpretasikan tulisan yang kita baca.

2. Literasi berarti juga kolaborasi. Kolaborasi atau bekerja sama dalam kegiatan belajar bahasa adalah tahap penting dalam proses belajar bahasa. Bekerja berpasangan dengan teman atau bahkan dengan gurunya sendiri harus didorong agar siswa memperoleh kepercayaan diri sebelum dapat menggunakan bahasanya secara mandiri.

3. Literasi juga menggunakan konvensi. Konvensi adalah kebiasaan-kebiasaan yang ada dalam budaya dan tercermin dalam berbagai aspek bahasa yang dipelajari.

4. Literasi melibatkan pengetahuan budaya. Penerapan konvesi yang benar tersebut lebih banyak didasarkan pada pengetahuan budaya.
5. Literasi adalah kemampuan untuk memecahkan masalah. Kegiatan belajar mengajar dalam pendekatan ini disarankan melibatkan proses berpikir untuk memecahkan masalah.

6. Literasi adalah kegiatan refleksi. Refleksi adalah kegiatan menilai penggunaan bahasa dirinya sendiri dan penggunaan bahasa orang lain yang menjadi lawan bicaranya.

7. Literasi adalah kemampuan menggunakan bahasa lisan dan tulis untuk menciptakan wacana.

Menurut Clay (2001) dan Ferguson (www.biblitech.us/pdfs/InfoLit.pdf) dalam (Wiedarti, 2016: 8-10), menjabarkan bahwa komponen literasi informasi terdiri atas literasi dini, literas dasar, literasi perpustakaan, literasi media, literasi teknologi, dan literasi visual. Dalam konteks Indonesia, literasi dini diperlukan sebagai dasar pemerolehan berliterasi tahap selanjutnya.

Abidin (2017: 22-23) mengemukakan bahwa pembelajaran literasi di sekolah dilaksanakan untuk mencapai tujuan tertentu. Sejalan dengan perkembangan definisi literasi, tujuan pembela-jaran literasi pun mengalami perubahan. Pada awalnya, pembelajaran literasi di sekolah hanya ditujukkan pada siswa terampil menguasai dimensi lingustik literasi. Dimensi-dimensi linguistik yang diharapkan dapat dikuasai oleh siswa antara lain sistem bahasa (mencakup fonem, morfem, grafofonemik, morfofonemik, dan sintaksis), konteks bahasa, dan variasi bahasa. Dalam perkembangan selanjutnya, pembelajaran literasi ditunjukan agar siswa mampu menguasai dimensi bahasa dan dimensi kognitif literasi (mencakup proses pemahaman, proses membaca, proses menulis, dan konsep analisis wacana tertulis).

Wiedarti (2016: 7), memberi penjelasan bahwa Gerakan Literasi Sekolah (GLS) merupakan suatu usaha atau kegiatan yang bersifat partisipatif dengan melibatkan warga sekolah (peserta didik, guru, kepala sekolah, tenaga kependidikan, pengawas sekolah, Komite Sekolah, orang tua/wali murid peserta didik), akademisi, penerbit, media massa, masyarakat (tokoh masyarakat yang dapat merepresentasikan keteladanan, dunia usaha, dll.), dan pemangku kepentingan di bawah koordinasi Direktorat Jenderal Pendidikan Dasar dan Menengah Kementrian Pendidikan dan Kebudayaan. 
Menurut Berrs (dalam Wiedarti, 2016: 11), praktik-praktik yang baik dalam gerakan literasi sekolah menekankan prinsip-prinsip sebagai berikut.

1. Perkembangan literasi berjalan sesuai tahap perkembangan yang dapat diprediksi. Tahap perkembangan anak dalam belajar membaca dan menulis saling beririsan antartahap perkembangan.

2. Program literasi yang baik bersifat berimbang. Sekolah yang menerapkan program literasi yang berimbang menyadari bahwa tiap peserta didik memiliki kebutuhan yang berbeda.

3. Program literasi terintegrasi dengan kurikulum.

4. Kegiatan membaca dan menulis dilakukan kapanpun.

5. Kegiatan literasi mengembangkan budaya lisan. Kelas berbasis literasi yang kuat diharapkan memunculkan berbagai kegiatan lisan berupa diskusi tentang buku selama pembelajaran di kelas.

6. Kegiatan literasi perlu mengembangkan kesadaran keberagaman.

Wiedarti (2016: 28) menjelaskan bahwa secara umum tahapan pelaksanaan Gerakan Literasi Sekolah dilakukan dalam tiga tahap sebagai berikut.

1. Tahap ke-1: Pembiasaan kegiatan membaca yang menyenangkan di ekosistem sekolah. Pembiasaan ini bertujuan menumbuhkan minat terhadap bacaan dan terhadap kegiatan membaca dalam diri warga sekolah. Penumbuhan minat baca merupakan hal fundamental bagi pengembangan kemampuan literasi peserta didik.

2. Tahap ke-2: Pengembangan minat baca untuk meningkatkan kemampuan literasi. Kegiatan literasi pada tahap ini bertujuan mengembangkan kemampuan memahami bacaan dan mengaitkannya dengan pengalaman pribadi, berpikir kritis, dan mengolah kemampuan komunikasi secara kreatif melalui kegiatan menanggapi bacaan pengayaan.

3. Tahap ke-3: Pembelajaran berbasis literasi. Kegiatan literasi pada tahap pembelajaran bertujuan mengembangkan kemampuan memahami teks dan mengaitkannya dengan pengalaman pribadi, berpikir kritis dan mengolah kemampuan komunikasi secara kreatif melalui kegiatan menanggapi teks buku bacaan pengayaan dan buku pelajaran.
Dalam tahap ini, ada tagihan yang sifatnya akademis (terkait dengan mata pelajaran).

Menurut Syah (2010: 45), terdapat beberapa faktor yang sangat berpengaruh dalam pelaksanaan literasi di sekolah. Faktor utama pendukung pelaksanaan literasi sekolah adalah adanya kuatnya payung hukum terhadap pelaksanaan literasi di sekolah. Faktor kedua adalah dukungan penuh dari pemerintah terhadap pelaksanaan Gerakan Literasi Sekolah. Faktor ketiga adalah sumber daya manusia (SDM) pengelola kegiatan Gerakan Literasi Sekolah SDM yang dimaksud adalah semua pemangku kepentingan (stakeholder) di tingkat pemerintah, dari tingkat pemerintahan pusat, LPMP, dinas pendidikan provinsi, kabupaten/kota, dan satuan pendidikan di itngkat kota. Faktor keempat, adalah dikeluarkannya Juknis pelaksanaan Gerakan Literasi Sekolah. Faktor kelima, orang tua peserta didik dan masyarakat yang tentunya mendukung penuh semua kegiatan postif untuk memajukan peserta didik. Faktor keenam, adalah peserta didik. Faktor ini merupakan fator penentu.

Di samping beberapa faktor pendukung pelaksanaan gerakan literasi di atas, terdapat beberapa faktor yang menjadi penghambat pelaksanaan gerakan literasi di sekolah. Faktor utama penghambat program literasi di sekolah adalah rendahnya minat baca peserta didik sebagai "sasaran" program tersebut. Artinya, kita harus mencari tahu faktor-faktor penyebab rendahnya minat baca peserta didik. Kita tidak boleh menutup mata bahwa rendahnya minat baca peserta didik hanyalah dampak negatif sebagai akibat faktor internal dan eksternal dari peserta didik (Syah, 2010: 47).

Menurut Pratiwi (2015: 83) prestasi belajar adalah perubahan yang diperoleh siswa setelah mengalami proses pembelajaran untuk mencapai tujuan pembelajaran yang diwujudkan dalam bentuk perbuatan. Perubahan ini biasanya dapat dilihat dari beberapa ranah, yaitu kognitif, afektif, dan psikomotorik pada diri siswa, untuk mengetahui hasilnya dapat diukur melalui tes ataupun pengamatan secara langsung.

Indikator prestasi belajar meliputi ranah kognitif, afektif, dan psikomotorik. Untuk mencapai prestasi yang baik tidak terlepas dari berbagai faktor yang mempengaruhinya. Menurut Suryabrata dalam (Pratiwi, 2015: 8283) faktor-faktor yang dapat mempengaruhi keberhasilan belajar dan prestasi belajar dapat 
digolongkan menjadi dua bagian, yaitu internal dan eksternal.

Faktor yang berasal dari dalam diri siswa meliputi dua aspek, yaitu aspek fisiologis (yang bersifat jasmaniah) dan aspek psikologis (yang bersifat rohaniah). Aspek fisiologis (jasmaniah) baik yang bersifat bawaan maupun yang diperoleh, kesehatan jasmani sangatlah besar pengaruhnya terhadap kemampuan belajar. Aspek psikologis baik yang bersifat bawaan maupun yang diperoleh seperti minat, bakat, intelegensi, motivasi, dan kemampuan kognitif seperti kemampuan persepsi, ingatan berpikir, dan kemampuan dasar bahan pengetahuan yang dimilikinya.

Faktor eksternal adalah faktor yang berasal dari luar diri siswa. Faktor-faktor yang berasal dari luar diri siswa yang bersangkutan juga digolongkan ke dalam dua bagian, yaitu faktor sosial dan faktor nonsosial. Faktor sosial menyangkut kehidupan manusia dengan lainnya saling membutuhkan dan di antara mereka tidak bisa hidup tanpa ada manusia lain yang membantu. Faktor nonsosial menyangkut sarana dan prasarana belajar, seperti keadaan suhu udara, waktu belajar, alat yang digunakan untuk belajar dapat pula memengaruhi prestasi belajar.

Hipotesis penelitian ini adalah program Gerakan Literasi Sekolah berpengaruh positif terhadap prestasi belajar Bahasa Indonesia siswa kelas IX SMP Negeri 10 Kendari.

\section{METODE PENELITIAN}

Pendekatan yang digunakan dalam penelitian ini yaitu pendekatan kuantitatif dengan metode yang digunakan yaitu metode penelitian ex post facto. Ex post facto artinya sesudah fakta. Penelitian ini tergolong penelitian kelas sebab dalam mengumpulkan data peneliti terlibat langsung di lapangan (sekolah) untuk mengumpulkan data penelitian.

Populasi dalam penelitian ini adalah siswa di SMP Negeri 10 Kendari tahun pelajaran 2019/2020 kelas IX yang berjumlah 232 siswa. Sampel dalam penelitian ini berjumlah 71 orang siswa kelas IX SMP Negeri 10 Kendari dengan teknik penarikan sampel yaitu Stratified Sampling

Menurut Sugiyono (2017: 60), variabel penelitian pada dasarnya adalah segala sesuatu yang berbentuk apa saja yang ditetapkan oleh peneliti untuk dipelajari sehingga diperoleh informasi tentang hal tersebut, kemudian ditarik kesimpulannya. Penelitian ini terdiri dari dua variabel yaitu variabel bebas (independen) dan variabel terikat (dependen). Variabel bebas dalam penelitian ini yaitu Program Gerakan Literasi Sekolah yang diberi simbol $\mathrm{X}$, dan variabel terikat dalam penelitian ini yaitu prestasi belajar Bahasa Indonesia yang diberi simbol Y. Teknik yang digunakan dalam pengumpulan data pada penelitian ini yaitu kuesioner (angket), teknik dokumentasi, dan teknik wawancara.

Instrumen yang digunakan dalam penelitian ini yaitu angket yang terdiri dari angket pengaruh program GLS. Angket disusun berdasarkan indikator program Gerakan Literasi Sekolah yang terdiri dari 25 butir pernyataan dengan pedoman penskoran menggunakan skala Likert. Angket yang digunakan telah di uji validitas dan reliabilitas sebelumnya sehingga 25 butir pernyataan dapat digunakan.

Teknik analisis data pada penelitian ini menggunakan bantuan SPSS versi 21 yang terdiri dari analisis deskriptif, analisis inferensial dan pengujian hipotesis. Analisis deskriptif digunakan untuk memberikan gambaran atau deskriptif suatu data sedangkan analisis inferensial digunakan untuk menganalisis pengaruh variabel $\mathrm{X}$ terhadap variabel Y. Analisis inferensial terdiri dari uji normalitas data dan uji linearitas data sedangkan untuk menguji hipotesis penelitian menggunakan analisis regresi linear sederhana yang diolah dengan menggunakan bantuan SPSS versi 21

\section{HASIL PENELITIAN DAN PEMBAHASAN}

Berdasarkan hasil analisis data output SPSS versi 21 program GLS menunjukkan bahwa dari 71 orang siswa kelas IX SMP Negeri 10 Kendari tahun pelajaran 2019/2020 yang menjadi sampel dalam penelitian ini memperoleh nilai rata-rata 75,82, median 76,00 , modus 82, standar deviasi 9,039, varian 81,695 , nilai maksimum 94 , dan nilai minimum 48. Deskripsi di atas dapat ditampilkan pada tabel 4.1 . 
Tabel 4.1

Distribusi Frekuensi Data Program Gerakan Literasi Sekolah

\begin{tabular}{ccccc}
\hline No & Interval & $\begin{array}{c}\text { Freku } \\
\text {-ensi }\end{array}$ & $(\boldsymbol{\%})$ & Kategori \\
\hline 1 & $\mathrm{X}<67$ & 11 & 15,5 & $\begin{array}{c}\text { Rendah } \\
2\end{array}$ \\
$67 \leq \mathrm{X}$ & 50 & 70,42 & Sedang \\
& $<85$ & & & \\
3 & $85 \leq \mathrm{X}$ & 10 & 14,08 & Tinggi \\
\hline & Total & 71 & 100 & \\
\hline
\end{tabular}

Berdasarkan distribusi frekuensi data program GLS yang disajikan dalam tabel $4.1 \mathrm{di}$ atas, dapat diketahui bahwa ada 11 orang atau $15,5 \%$ siswa berada pada kategori rendah, 50 orang atau $70,42 \%$ siswa berada dikategori sedang, dan terdapat 10 orang atau 14,08\% siswa berada pada kategori tinggi.

Berdasarkan hasil analisis data output SPSS versi 21 prestasi belajar Bahasa Indonesia siswa menunjukkan bahwa dari 71 orang siswa kelas VII SMP Negeri 10 Kendari tahun pelajaran 2017/2018 yang menjadi sampel dalam penelitian ini memperoleh nilai rata-rata 81,49 , nilai maksimum 90 , dan nilai minimum 70. Varian 21,682, modus 84, dan standar deviasi 4,656. Selanjutnya distribusi frekuensi prestasi belajar Bahasa Indonesia serta pie charts dapat dilihat pada tabel 4.2.

Tabel 4.2

Distribusi Frekuensi Data Prestasi Belajar Bahasa Indonesia Siswa SMP Negeri 10 Kendari Sebelum Dilaksanakan Program Gerakan Literasi Sekolah

\begin{tabular}{cccc}
\hline $\begin{array}{c}\text { Interval } \\
\text { Nilai }\end{array}$ & $\begin{array}{c}\text { Freku- } \\
\text { ensi }\end{array}$ & $\begin{array}{c}\text { Persentase } \\
\text { \% }\end{array}$ & Keterangan \\
\hline $90-$ & 2 & 2,8 & Sangat Baik \\
100 & & & \\
$80-89$ & 48 & 67,6 & Baik \\
$70-79$ & 21 & 29,6 & Cukup \\
$<70$ & 0 & 0 & Kurang \\
\hline Total & 71 & 100 & \\
\hline
\end{tabular}

Berdasarkan distribusi frekuensi dan pie charts yang disajikan dalam tabel 4.2 tersebut, diketahui bahwa sebelum dilaksanakan kegiatan literasi sekolah, siswa SMP Negeri 10 Kendari sebanyak 71 orang siswa sebagai sampel terbagi menjadi tiga kelompok yaitu terdapat 2 orang atau $2,8 \%$ berada pada kelompok sangat baik, terdapat 48 orang atau $67,6 \%$ berada pada kelompok baik, dan terdapat 21 orang atau $29,6 \%$ berada pada kelompok cukup.

Hasil analisis data output SPSS versi 21 prestasi belajar Bahasa Indonesia menunjukkan bahwa dari 71 orang siswa kelas IX SMP Negeri 10 Kendari tahun pelajaran 2019/2020 yang menjadi sampel dalam penelitian ini memperoleh nilai rata-rata 84,31, nilai maksimum 92, dan nilai minimum 75 . Varian 23,503, modus 90, dan standar deviasi 4,848. Selanjutnya distribusi frekuensi prestasi belajar Bahasa Indonesia dapat dilihat pada tabel 4.3.

Tabel 4.3

Distribusi Frekuensi Data Prestasi Belajar Bahasa Indonesia Siswa Kelas IX SMP Negeri 10 Kendari Setelah Dilaksanakan Program Gerakan Literasi Sekolah

\begin{tabular}{cccc}
\hline $\begin{array}{c}\text { Interval } \\
\text { Nilai }\end{array}$ & $\begin{array}{c}\text { Freku- } \\
\text { ensi }\end{array}$ & $(\boldsymbol{\%})$ & Keterangan \\
\hline $90-100$ & 16 & 22,5 & Sangat Baik \\
$80-89$ & 43 & 60,5 & Baik \\
$70-79$ & 12 & 17 & Cukup \\
$<70$ & 0 & 0 & Kurang \\
\hline Total & 71 & 100 & \\
\hline
\end{tabular}

Berdasarkan distribusi frekuensi yang disajikan dalam tabel 4.3 tersebut, diketahui bahwa setelah dilaksanakan kegiatan literasi, siswa SMP Negeri 10 Kendari sebanyak 71 orang siswa sebagai sampel terbagi menjadi tiga kelompok yaitu siswa yang berada di kelompok sangat baik sebanyak 16 orang atau $22,5 \%$, siswa yang berada di kelompok baik sebanyak 43 orang atau 60,5\%, dan terdapat 12 orang atau $17 \%$ siswa berada pada kelompok kategori cukup.

Selanjutnya, untuk mengetahui apakah ada perubahan nilai rapor Bahasa Indonesia sebelum dan setelah dilaksanakan kegiatan literasi, dapat dilihat dari perbandingan nilai siswa. Untuk prestasi belajar siswa sebelum dilaksanakan kegiatan literasi, diambil berdasarkan nilai rapor Bahasa Indonesia siswa kelas VIII tahun pelajaran 2018/2019 sebanyak 71 orang siswa yang menjadi sampel dalam penelitian ini. Prestasi belajar Bahasa Indonesia siswa setelah dilaksanakan kegiatan literasi diambil berdasarkan nilai rapor Bahasa Indonesia siswa kelas IX tahun pelajaran 2019/2020 dengan sampel yang sama. Kemudian kedua nilai tersebut dibandingkan, kemudian dapat dilihat apakah ada peningkatan, penurunan, atau bahkan tidak mengalami peningkatan ataupun penurunan.

Berdasarkan hasil perbandingan nilai sebelum dan sesudah literasi, menunjukkan bahwa dari 71 orang siswa sebagai sampel terbagi menjadi tiga kategori. Terdapat 54 orang atau $76,06 \%$ siswa yang mengalami peningkatan nilai setelah dilaksanakan kegiatan literasi, terdapat 4 orang atau $5,63 \%$ siswa 
yang tidak mengalami peningkatan bahkan penurunan nilai, dan terdapat 13 orang atau $18,31 \%$ siswa yang mengalami penurunan nilai setelah dilaksanakan kegiatan literasi.

Uji normalitas data penelitian bertujuan untuk mengetahui apakah data penelitian berdistribusi normal atau tidak. Dalam penelitian ini dilakukan uji normalitas data dengan menggunakan uji KolmogorovSmirnov. Pengujian normalitas data dilakukan dengan menggunakan bantuan program SPSS versi 21. Hasil output uji normalitas tersebut menunjukkan bahwa nilai Asymp. Sig. (2tailed) yaitu 0,200. Karena nilai Asymp. Sig. (2-tailed) yaitu 0,200 >0,05, maka data kedua variabel dapat dikatakan berdistribusi normal dan penelitian dapat dilanjutkan.

Uji linearitas bertujuan untuk mengetahui apakah dua variabel mempunyai hubungan yang linear atau tidak secara signifikan. Berdasarkan hasil uji linearitas data yang disajikan pada tabel 4.6 di atas, maka dapat disimpulkan bahwa Deviation from Linearity hubungan antara data variabel program Gerakan Literasi Sekolah (X) dan prestasi belajar Bahasa Indonesia (Y) yaitu 0,382 > 0,05 , dengan demikian variabel $\mathrm{X}$ dan variabel Y memiliki hubungan yang linear secara signifikan.

Setelah pengujian normalitas data dan linearitas data dilakukan, selanjutnya dilakukan pengujian hipotesis penelitian. Pengujian hipotesis pada penelitian ini menggunakan analisis regresi linear sederhana. Hasil analisis regresi linear sederhana kedua variabel tersebut dapat dilihat pada tabel 4.4 berikut.

\section{Tabel 4.4}

Uji Regresi Linear Sederhana Variabel X dan Y

Coefficients

\begin{tabular}{|c|c|c|c|c|c|c|}
\hline & \multirow{2}{*}{ Model } & \multicolumn{2}{|c|}{$\begin{array}{l}\text { Unstandardize } \\
\text { d Coefficients }\end{array}$} & $\begin{array}{l}\text { Standar- } \\
\text { dized } \\
\text { Coeffi- } \\
\text { cients } \\
\end{array}$ & \multirow{2}{*}{$\mathrm{T}$} & \multirow{2}{*}{ Sig. } \\
\hline & & B & $\begin{array}{l}\text { Std. } \\
\text { Error }\end{array}$ & Beta & & \\
\hline \multirow{2}{*}{1} & $\begin{array}{l}\text { (Cons- } \\
\text { tant) }\end{array}$ & 74,300 & 4,778 & & 15,550 & ,000 \\
\hline & $\begin{array}{l}\text { Program } \\
\text { GLS }\end{array}$ & ,132 & ,063 & ,246 & 2,110 & ,039 \\
\hline
\end{tabular}

Berdasarkan tabel 4.4, dapat diketahui nilai Constant (a) sebesar 74,300, sedangkan nilai Trust (b / koefisien regresi) sebesar 0,132, sehingga persamaan regresinya dapat ditulis sebagai berikut.

$$
\begin{aligned}
& Y=a+b X \\
& Y=74,300+0,132 X
\end{aligned}
$$

Persamaan tersebut dapat diterjemahkan bahwa konstanta sebesar 74,300 mengandung arti bahwa nilai konsisten variabel prestasi belajar Bahasa Indonesia adalah sebesar 74,300 . Sedangkan koefisien regresi $X$ sebesar 0,132 mengandung arti bahwa setiap penambahan $1 \%$ nilai program Gerakan Literasi Sekolah, maka nilai prestasi belajar Bahasa Indonesia bertambah sebesar 0,132. Koefisien regresi tersebut bernilai positif, sehingga dapat dikatakan bahwa arah pengaruh variabel $\mathrm{X}$ terhadap variabel $\mathrm{Y}$ adalah positif.

Berdasarkan tabel 4.4 di atas, dapat dilihat bahwa nilai signifikansi (Sig.) sebesar 0,039. Jika dibandingkan dengan nilai probabilitas atau $\alpha=0,05$, maka $0,039<0,05$, yang berarti $\mathrm{H}_{0}$ ditolak dan $\mathrm{H}_{\mathrm{a}}$ diterima. Sehingga dapat disimpulkan bahwa variabel program Gerakan Literasi Sekolah (X) berpengaruh terhadap variabel prestasi belajar Bahasa Indonesia (Y). Berdasarkan nilai $t$, diketahui nilai $t_{\text {hitung }}$ sebesar 2,110 , sedangkan nilai $t_{\text {tabel }}$ dapat dicari dengan cara berikut ini.

$$
\begin{aligned}
\mathbf{t}_{\text {tabel }} & =(\alpha / 2: \mathrm{n}-\mathrm{k}-1) \\
& =(0,05 / 2: 71-1-1) \\
& =(0,025: 69) \\
& =1,994
\end{aligned}
$$

Berdasarkan hasil perhitungan nilai $t_{\text {tabel, }}$ maka nilai $t_{\text {hitung }}$ sebesar $2,110>t_{\text {tabel }} 1,994$, yang berarti $\mathrm{H}_{0}$ ditolak dan $\mathrm{H}_{\mathrm{a}}$ diterima sehingga dapat disimpulkan bahwa variabel program Gerakan Literasi Sekolah (X) berpengaruh terhadap variabel prestasi belajar Bahasa Indonesia (Y).

Besarnya pengaruh variabel bebas terhadap variabel terikat ditentukan dari nilai $\mathrm{R}$ square. Jika R square sama dengan 0 , maka tidak ada sedikitpun persentase sumbangan pengaruh yang diberikan variabel bebas terhadap variabel terikat. Sebaliknya semakin mendekati 1 maka persentase sumbangan pengaruh yang diberikan variabel bebas terhadap variabel terikat semakin mendekati sempurna (Raharjo, 2014). Berdasarkan tabel 4.8, diperoleh nilai R Square (koefisien determinasi) sebesar 0,061 atau 6,1\%. Hal ini menunjukkan bahwa program Gerakan Literasi Sekolah mempengaruhi prestasi belajar Bahasa Indonesia sebesar $6,1 \%$ dan sisanya 93,9\% dipengaruhi oleh faktor lain.

Berdasarkan hasil wawancara yang dilakukan kepada Bapak Kepala SMP Negeri 10 Kendari yang menjelaskan bahwa dalam 
pelaksanaannya siswa sangat antusias dalam membaca buku namun ada beberapa faktor yang menjadi penghambat dan pendukung dalam pelaksanaan program literasi sekolah tersebut. Faktor penghambatnya yaitu lingkungan keluarga siswa dan kurangnya petugas literasi, sedangkan faktor pendukungnya yaitu adanya dukungan dari pelaksana yaitu pihak sekolah dan bahan bacaan atau buku sudah memadai.

Faktor lain yang mempengaruhi pelaksanaan kegiatan literasi juga dijelaskan oleh salah satu guru Bahasa Indonesia kelas IX yang menjelaskan bahwa faktor utama yang mempengaruhi pelaksanaan kegiatan literasi adalah siswa itu sendiri dalam hal ini kemauan siswa dalam membaca. Faktor tersebut merupakan salah satu faktor internal. Selain itu, faktor lain yang mempengaruhi pelaksanaan kegiatan literasi yaitu ketidakdisiplinan guru yang mengajar pada jam pertama. Melihat faktor tersebut, sehingga solusi yang diberikan petugas literasi yaitu dengan mengadakan literasi di lapangan sekolah.

Pelaksanaan program Gerakan Literasi Sekolah di SMP Negeri 10 Kendari banyak memberi manfaat bagi siswa dan apresiasi siswa terhadap kegiatan tersebut sangat baik. Sebagian besar siswa setuju dengan kegiatan literasi, karena menurut mereka kegiatan literasi dapat meningkatkan minat baca dan pemahamannya terhadap wacana. Namun ada juga beberapa siswa yang menunjukkan ketidaksetujuan terhadap pelaksanaan kegiatan literasi. Sebab kegiatan tersebut tidak memberikan dampak terhadap minat baca dan prestasi belajar Bahasa Indonesia. Faktor lain yang mempengaruhi pelaksaan kegiatan literasi yaitu tidak adanya kemauan siswa dalam membaca, lingkungan kelas yang tidak kondusif, dan kurangnya pengawasan dalam pelaksaanannya.

Berdasarkan hasil wawancara tersebut, dapat dilihat bahwa banyak faktor yang mempengaruhi pelaksaanaan program literasi sekolah dan prestasi belajar Bahasa Indonesia siswa, baik itu faktor internal siswa maupun faktor eksternal yang berupa lingkungan keluarga atau lingkungan sekolah.

Variabel program Gerakan Literasi Sekolah adalah variabel dalam penelitian ini yang dianggap dapat memberikan kontribusi dan pengaruh terhadap prestasi belajar Bahasa Indonesia siswa. Berdasarkan data hasil analisis deskriptif program Gerakan Literasi
Sekolah terhadap 71 orang siswa kelas IX sebagai responden dalam penelitian ini, menunjukkan bahwa terdapat 11 orang atau $15,5 \%$ siswa berada pada kategori rendah, 50 orang atau $70,42 \%$ siswa berada dikategori sedang, dan terdapat 10 orang atau 14,08\% siswa berada pada kategori tinggi.

Berdasarkan data hasil analisis deskriptif prestasi belajar Bahasa Indonesia sebelum dilaksanakan kegiatan literasi terhadap 71 orang siswa sebagai responden, yang menunjukkan bahwa siswa yang berada di kelompok sangat baik sebanyak 2 orang atau $2,8 \%$, siswa yang berada di kelompok baik sebanyak 48 orang atau $67,6 \%$, dan terdapat 21 orang atau $29,6 \%$ siswa berada pada kelompok kategori cukup.

Berdasarkan data hasil analisis deskriptif prestasi belajar Bahasa Indonesia siswa setelah dilaksanakan kegiatan literasi terhadap 71 orang siswa kelas IX sebagai responden, yang menunjukkan bahwa siswa yang berada di kelompok sangat baik sebanyak 16 orang atau $22,5 \%$, siswa yang berada di kelompok baik sebanyak 43 orang atau $60,50 \%$, dan terdapat 12 orang atau $17 \%$ siswa berada pada kelompok kategori cukup.

Untuk melihat adanya pengaruh literasi terhadap prestasi belajar Bahasa Indonesia siswa, peneliti membandingkan nilai rapor Bahasa Indonesia siswa sebelum dilaksanakan kegiatan literasi dan nilai rapor Bahasa Indonesia siswa setelah dilaksanakan kegiatan literasi. Berdasarkan distribusi frekuensi data prestasi belajar Bahasa Indonesia siswa sebelum dan setelah dilaksanakan kegiatan literasi, menunjukkan bahwa dari 71 orang siswa sebagai sampel terbagi menjadi tiga kategori. Terdapat 54 orang atau 76,06\% siswa yang mengalami peningkatan nilai setelah dilaksanakan kegiatan literasi, terdapat 4 orang atau $5,63 \%$ siswa yang tidak mengalami peningkatan bahkan penurunan nilai, dan terdapat 13 orang atau $18,31 \%$ siswa yang mengalami penurunan nilai setelah dilaksanakan kegiatan literasi. Dalam hal ini, kegiatan literasi dapat memberikan konstribusi dan pengaruh yang signifikan terhadap prestasi belajar Bahasa Indonesia siswa, walaupun ada beberapa siswa yang mengalami penurunan nilai dan penurunan tersebut dapat dipengaruhi oleh beberapa faktor.

Berdasarkan hasil analisis pengujian hipotesis antara program Gerakan Literasi Sekolah dengan prestasis belajar Bahasa 
Indonesia diperoleh nilai konstanta sebesar 74,300 mengandung arti bahwa nilai konsisten variabel prestasi belajar Bahasa Indonesia adalah sebesar 74,300. Sedangkan koefisien regresi $\mathrm{X}$ sebesar 0,132 mengandung arti bahwa setiap penambahan $1 \%$ nilai program Gerakan Literasi Sekolah, maka nilai prestasi belajar Bahasa Indonesia bertambah sebesar 0,132. Koefisien regresi tersebut bernilai positif, sehingga dapat dikatakan bahwa arah pengaruh variabel $\mathrm{X}$ terhadap variabel $\mathrm{Y}$ adalah positif.

Jika dilihat dari nilai Sig. hasil analisis regresi linear sederhana, diperoleh nilai signifikansi (Sig.) sebesar 0,039. Jika dibandingkan dengan nilai probabilitas atau $\alpha=$ 0,05 , maka $0,039<0,05$, yang berarti $\mathrm{H}_{0}$ ditolak dan $\mathrm{H}_{\mathrm{a}}$ diterima. Sehingga dapat disimpulkan bahwa variabel program Gerakan Literasi Sekolah (X) berpengaruh terhadap variabel prestasi belajar Bahasa Indonesia (Y). Hal ini juga dapat dilihat dari hasil uji koefisien determinasi yang mengungkapkan kontribusi program Gerakan Literasi Sekolah untuk prestasi belajar Bahasa Indonesia adalah $6,1 \%$. Walaupun kontribusi yang diberikan masih sangat rendah, namun jika program tersebut dilaksanakan dengan sangat baik dengan melihat faktor-faktor yang mempengaruhi pelaksanaannya maka pengaruhnya terhadap prestasi belajar Bahasa Indonesia bisa meningkat.

Hasil penelitian ini relevan dengan penelitian yang dilakukan oleh Fajarwati, Yunitha (2016) yang berjudul "Pengaruh Kemampuan Literasi Informasi terhadap Prestasi Belajar Siswa SMAN 1 Depok". Dimana pada penelitian tersebut menunjukan dari hasil uji statistik diperoleh nilai $\mathrm{p}<0,05$, jadi dapat disimpulkan bahwa terdapat pengaruh antara kemampuan literasi informasi dengan prestasi belajar siswa. Dengan demikian, dapat diambil kesimpulan bahwa terdapat pengaruh linear kemampuan literasi informasi terhadap prestasi belajar siswa.

Berdasarkan uraian di atas, dalam hasil penelitian ini telah dijabarkan bahwa antara program Gerakan Literasi Sekolah dengan prestasi belajar Bahasa Indonesia memiliki pengaruh yang positif dan signifikan. Meskipun kontribusi yang diberikan masih tergolong rendah. Hal ini dapat terjadi karena, setiap responden atau sampel dalam penelitian ini memiliki faktor-faktor yang mempengaruhi prestasi belajar yang berbeda-beda.
Untuk mengetahui informasi tentang bagaimana pelaksanaan program Gerakan Literasi Sekolah dan pengaruhnya terhadap prestasi belajar Bahasa Indonesia siswa, peneliti melakukan wawancara kepada beberapa narasumber terdiri dari kepala sekolah, guru Bahasa Indonesia kelas IX, dan siswa kelas IX.

Berdasarkan hasil wawancara yang dilakukan kepada narasumber pertama yaitu kepala sekolah SMP Negeri 10 Kendari yang menyatakan bahwa program Gerakan Literasi Sekolah memberikan dampak yang positif bagi siswa sebab program tersebut merupakan salah satu poin untuk mencerdaskan anak dalam pembiasan membaca. Pelaksanaan kegiatan literasi di sekolah telah berjalan sesuai dengan prosedur yang telah ditetapkan. Selama kegiatan berlangsung siswa antusias dalam membaca buku, terutama setelah membaca siswa diberi kesempatan untuk mepresentasikan dan memberi tanggapan tentang apa yang telah mereka baca. Dengan demikian, siswa akan terbiasa tampil di depan untuk berbicara dan kecerdasan siswa pun dilatih dengan kegiatan literasi ini.

Faktor-faktor yang mempengaruhi pelaksanaan kegiatan literasi ini terdiri dari dua faktor yaitu faktor penghambat dan faktor pendukung. Faktor yang menjadi penghambat dalam kegiatan literasi salah satunya yaitu lingkungan keluarga yang mempengaruhi psikologis siswa itu sendiri. Dalam hal ini, lingkungan keluarga yang harmonis akan berpengaruh dengan psikologis siswa begitu pula sebaliknya. Misalnya, orang tua siswa kurang memperhatikan anaknya dalam belajar terutama ketika di rumah, sehingga kebiasaan siswa di rumah seperti malas akan terbawa sampai ke sekolah.

Faktor penghambat yang ke dua yaitu kurangnya petugas literasi. Pelaksanaan kegiatan literasi ini di pandu oleh petugas khusus dari sekolah literasi dan di SMP Negeri 10 Kendari petugas literasi yang bertugas hanya dua orang, sehingga ini menjadi salah satu penghambat jalannya kegiatan literasi tersebut. Walaupun petugasnya tergolong sedikit, namun pelaksanaannya tetap berjalan sesuai dengan prosedur. Faktor pendukung pelaksanaan kegiatan literasi yaitu buku-buku yang memadai. Penyediaan bahan bacaan yang memadai membuat siswa dengan mudah dapat membaca satu buku untuk satu orang siswa dan bisa juga bergantian. 
Adanya dukungan dari pihak sekolah menjadi faktor pendukung dalam pelaksanaan kegiatan literasi. Sekolah sangat mendukung kegiatan literasi tersebut, sebab dapat memberikan dampak yang positif walaupun dengan berbagai kendala yang ada. Namun berbagai upaya juga akan dilakukan pihak sekolah untuk meminimalisir adanya hambatan dan kekurangan selama kegiatan berlangsung.

Berdasarkan hasil wawancara yang dilakukan oleh salah satu guru Bahasa Indonesia kelas IX di SMP Negeri 10 Kendari yang menyatakan bahwa sebuah kegiatan tentunya dipengaruhi oleh beberapa faktor. Faktor utama yang mempengaruhi pelaksanaan kegiatan literasi adalah siswa itu sendiri. Dalam hal ini siswa yang mengambil peran penting sebab kegiatan literasi ditujukan untuk siswa. Guru dan petugas literasi telah menjalankan kegiatan dengan sebaik-baiknya namun semua kembali pada diri siswa masingmasing.

Faktor lain yang mempengaruhi pelaksanaan kegiatan literasi yaitu ketidakdisiplinan guru yang mengajar pada jam pertama. Kegiatan literasi ini dilakukan 20 menit sebelum jam pertama dimulai dan ketika guru yang mengajar pada jam pertama tidak disiplin tentunya berdampak pada kegiatan literasi tersebut, siswa tidak membaca karena tidak ada yang mengawasi. Melihat faktor tersebut, solusi yang diberikan petugas literasi yaitu dengan mengadakan literasi di lapangan sekolah, dengan demikian pelaksanaannya lebih efektif dan siswa dapat dengan mudah dikontrol.

Berdasarkan hasil wawancara yang dilakukan oleh beberapa siswa kelas IX ada yang menyatakan bahwa setuju dengan adanya kegiatan literasi dan ada pula yang tidak setuju dengan adanya kegiatan literasi. Siswa yang setuju menyatakan bahwa kegiatan literasi dapat memberikan dampak positif bagi dirinya dan minat bacanya mengalami peningkatan. Kemampuan dalam memahami wacana pun meningkat sehingga prestasi belajar Bahasa Indonesia juga mengalami peningkatan. Sedangkan siswa yang tidak setuju dengan kegiatan literasi menyatakan bahwa kegiatan tersebut tidak memberikan kontribusi bagi prestasi belajar Bahasa Indonesia. Prestasi belajarnya tidak mengalami perubahan setelah dilaksanakan kegiatan literasi. Salah satu faktor yang mempengaruhi hal tersebut yaitu tidak adanya kemauan dan minat siswa dalam membaca dan faktor lingkungan sekolah juga menjadi faktor yang berpengaruh. Keberadaan media sosial juga sangat berpengaruh dalam pelaksanaan kegiatan literasi dan menjadi ancaman serius bagi keberadaan dan fungsi buku sebagai media literasi. Siswa lebih suka membaca di media sosial dibandingkan membaca buku.

Berdasarkan uraian di atas, ada dua faktor yang mempengaruhi pelaksanaan program Gerakan Literasi Sekolah yaitu faktor penghambat yang terdiri dari lingkungan keluarga dan kurangnya petugas literasi yang bertugas, sedangkan faktor pendukungnya yaitu penyediaan buku yang telah memadai dan adanya dukungan dari pihak sekolah. Selain itu faktor yang mempengaruhi prestasi belajar Bahasa Indonesia siswa terdiri dari faktor internal dan faktor eksternal. Faktor internal yang mempengaruhi prestasi belajar siswa yaitu aspek psikologis yang terdiri dari minat baca dan kemauan siswa sedangkan faktor eksternal yang mempengaruhi yaitu lingkungan sekolah dan keberadaan media sosial.

Program Gerakan Literasi Sekolah berperan dalam meningkatkan prestasi belajar Bahasa Indonesia siswa. Artinya, jika prestasi belajar Bahasa Indonesias siswa diinginkan meningkat maka siswa harus meningkatkan minat bacanya dalam kegiatan literasi sekolah.

\section{KESIMPULAN DAN SARAN}

Berdasarkan hasil analisis dan pembahasan yang dikemukakan pada bab sebelumnya, maka dapat ditarik simpulan sebagai berikut.

1. Ada pengaruh yang positif dan signifikan program Gerakan Literasi Sekolah terhadap prestasi belajar Bahasa Indonesia siswa kelas IX SMP Negeri 10 Kendari Tahun Pelajaran 2019/2020 dengan nilai signifikansi (Sig.) sebesar 0,039 yang menunjukkan bahwa ada pengaruh yang positif dan program Gerakan Literasi Sekolah memiliki kontribusi untuk prestasi belajar Bahasa Indonesia siswa.

2. Ada dua faktor yang mempengaruhi pelaksanaan program Gerakan Literasi Sekolah yaitu faktor penghambat yang terdiri dari lingkungan keluarga dan kurangnya petugas literasi yang bertugas, sedangkan faktor pendukungnya yaitu penyediaan buku yang telah memadai. Selain itu faktor yang mempengaruhi prestasi belajar Bahasa Indonesia siswa terdiri dari faktor internal dan faktor 
eksternal. Faktor internal yang mempengaruhi prestasi belajar siswa yaitu aspek psikologis sedangkan faktor eksternal yang mempengaruhi yaitu lingkungan sekolah.

Berdasarkan temuan penelitian dan pembahasan, maka dikemukakan beberapa saran sebagai berikut.

1. Bagi sekolah, dalam pelaksanaan program Gerakan Literasi Sekolah agar lebih meningkatkan keefektifannya dan memberikan lingkungan membaca yang nyaman dengan melengkapi fasilitas yang diperlukan untuk membaca baik di dalam ruangan maupun di luar ruangan. Diharapkan kepada guru agar dapat melakukan kegiatan literasi terhadap mata pelajaran Bahasa Indonesia.

2. Bagi siswa, siswa diharapkan lebih banyak dan giat untuk membaca buku di perpustakaan atau di luar sekolah yang berhubungan dengan mata pelajaran Bahasa Indonesia dan diharapkan untuk selalu aktif dalam kegiatan belajar mengajar di sekolah serta selalu memperhatikan dan mendengarkan guru ketika pelajaran dimulai sehingga mengerti apa yang diajarkan oleh guru.

3. Diharapkan kepada peneliti selanjutnya untuk melakukan penelitian serupa dengan materi yang berbeda.

\section{DAFTAR PUSTAKA}

Abidin, Yunus, dkk. 2017. Pembelajaran Literasi. Jakarta: Bumi Aksara.

Atmazaki, dkk. 2017. Panduan Gerakan Literasi Nasional. Jakarta: Direktorat Jenderal Pedidikan Dasar dan Menengah Kementrian Pendidikan dan Kebudayaan. (E Book) diakses tanggal 4 Maret 2019.

Hafid, Anwar, dkk. 2013. Konsep Dasar Ilmu Pendidikan. Bandung: Alfabeta.

Hayat, Bahrul dan Yusuf Suhendar. 2015. Benchmark International Mutu Pendidikan. Jakarta: PT Bumi Aksara.

Imran, dkk. 2017. Budaya Literasi Melalui Program GLS dalam Menumbuhkembangkan Minat Baca Siswa SD Negeri Melayu. Jurnal Penelitian dan Penalaran, No: 1, Vol 4.

Pratiwi, Noor Komari. 2015. Pengaruh Tingkat Pendidikan, Perhatian Orang Tua, dan Minat Belajar Siswa Terhadap Prestasi Belajar Bahasa Indonesia Siswa SMK
Kesehatan Di Kota Tangerang. Jurnal Pujangga, No: 2, Vol 1.

Raharjo, Sahid. 2014. Cara Melakukan Uji Statistik Deskriptif dengan Software SPSS. Www.spssindonesia.com. 12 Oktober 2019.

Raharjo, Sahid. 2014. Cara Melakukan Uji Normalitas Kolmogorov-Smirnov dengan $\begin{array}{ll}\text { SPSS. } \quad \text { www.spssindonesia.com. } & 12\end{array}$ Oktober 2019.

Raharjo, Sahid. 2014. Cara Melakukan Uji Linearitas dengan Program SPSS. www.spssindonesia.com. 12 Oktober 2019.

Raharjo, Sahid. 2014. Panduan Lengkap Uji Analisis Regresi Linear Sederhana dengan SPSS. www.spssindonesia.com. 12 Oktober 2019.

Retnaningdyah, Pratiwi, dkk. 2016. Panduan Gerakan Literasi Sekolah Di Sekolah Menengah Pertama. Jakarta: Direktorat Jenderal Pedidikan Dasar dan Menengah Kementrian Pendidikan dan Kebudayaan. (E Book) diakses tanggal 4 Maret 2019.

Sahlan. 2018. Penelitian Pengajaran \& Tindakan Kelas. Kendari. Jurusan Pendidikan Bahasa dan Sastra Indonesia.

Sudjana, Nana dan Ibrahim. 2004. Penelitian dan Penilaian Pendidikan. Bandung: Sinar Baru Algesindo.

Sugiyono. 2017. Metode Penelitian Pendidikan Pendekatan Kuantitatif, Kualitatif, dan $R \& D$. Bandung: Alfabeta.

Sugiyono. 2018. Metode Penelitian Kuantitatif. Bandung: Alfabeta.

Syafi'i, Ahmad, dkk. 2018. Studi Tentang Prestasi Belajar Siswa dalam Berbagai Aspek dan Faktor yang Mempengaruhi. Jurnal Komunikasi Pendidikan, No: 2, Vol 2.

Syah, Muhibbin. 2010. Psikologi Pendidikan dengan Pendekatan Baru. Bandung: PT Remaja Rosdakarya Offset.

Syah, Muhibbin. 2013. Psikologi Belajar. Jakarta: PT RajaGrafindo Persada.

Wiedarti, Pangesti, dkk. 2016. Desain Induk Gerakan Literasi Sekolah. Jakarta: Direktorat Jenderal Pedidikan Dasar dan Menengah Kementrian Pendidikan dan Kebudayaan. (E Book) diakses tanggal 4 Maret 2019. 